\title{
Mercury deposition in Southern New Hampshire, 2006-2009
}

\author{
M. A. S. Lombard ${ }^{1}$, J. G. Bryce ${ }^{1}$, H. Mao ${ }^{2}$, and R. Talbot ${ }^{3}$ \\ ${ }^{1}$ Department of Earth Sciences, University of New Hampshire, Durham, NH, 03824, USA \\ ${ }^{2}$ Department of Chemistry, State University of New York's College of Environmental Science and Forestry, Syracuse, NY, \\ 13210, USA \\ ${ }^{3}$ Department of Earth and Atmospheric Sciences, University of Houston, Houston, TX, 77204, USA \\ Received: 5 January 2011 - Published in Atmos. Chem. Phys. Discuss.: 8 February 2011 \\ Revised: 11 July 2011 - Accepted: 12 July 2011 - Published: 1 August 2011
}

\begin{abstract}
The atmospheric deposition of mercury ( $\mathrm{Hg}$ ) occurs via several mechanisms including wet, dry, and occult processes. In an effort to understand the atmospheric cycling and seasonal depositional characteristics of $\mathrm{Hg}$, event-based wet deposition samples and reactive gaseous $\mathrm{Hg}$ (RGM) measurements were collected for approximately 3 years at Thompson Farm (TF), a near-coastal rural site in Durham, $\mathrm{NH}$, part of the University of New Hampshire AIRMAP Observing Network. Total aqueous mercury exhibited seasonal patterns in $\mathrm{Hg}$ wet deposition at TF. The lowest $\mathrm{Hg}$ wet deposition was measured in the winter with an average total seasonal deposition of $1.56 \mu \mathrm{g} \mathrm{m}^{-2}$ compared to the summer average of $4.71 \mu \mathrm{g} \mathrm{m}^{-2}$. Inter-annual differences in total wet deposition are generally linked with precipitation volume, with the greatest deposition occurring in the wettest year. Relationships between surface level RGM and Hg wet deposition were also investigated based on continuous RGM measurements at TF from November 2006 to September 2009. No correlations were observed between RGM mixing ratios and $\mathrm{Hg}$ wet deposition, however the ineffective scavenging of RGM during winter precipitation events was evidenced by the less frequent depletion of RGM below the detection level. Seasonal dry deposition of reactive gaseous $\mathrm{Hg}$ (RGM) was estimated using an order-of-magnitude approach. RGM mixing ratios and dry deposition estimates were greatest during the winter and spring. The seasonal ratios of $\mathrm{Hg}$ wet deposition to RGM dry deposition vary by up to a factor of 80 .
\end{abstract}

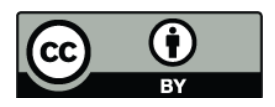

Correspondence to: M. A. S. Lombard (mas3@cisunix.unh.edu)

\section{Introduction}

Mercury $(\mathrm{Hg})$ is a naturally occurring contaminant of global concern due to its toxicity and ubiquitous presence in the atmosphere. It exists in diverse chemical forms comprised of gaseous elemental mercury $\left(\mathrm{Hg}^{\circ}\right)$, reactive gaseous mercury $\left(\mathrm{RGM}=\mathrm{HgCl}_{2}+\mathrm{HgBr}_{2}+\mathrm{HgOBr}+\ldots\right)$, and particulate mercury $\left(\mathrm{Hg}^{P}\right)$. Deposition of atmospheric $\mathrm{Hg}$, mainly the more soluble forms of RGM and $\mathrm{Hg}^{P}$, is an important source of $\mathrm{Hg}$ to terrestrial (Rea et al., 2002; Bushey et al., 2008; Choi et al., 2008; Selvendiran et al., 2008) and aquatic ecosystems (Landis and Keeler, 2002; Ariya et al., 2004). Methylated forms of $\mathrm{Hg}$ bioaccumulate in fish, and their consumption is the major exposure route of $\mathrm{Hg}$ to humans (Downs et al., 2007).

Previous studies suggest that the magnitude of $\mathrm{Hg}$ wet deposition varies geographically and seasonally due to climatic conditions, atmospheric chemistry, and human influences (VanArsdale et al., 2005; Selin and Jacob, 2008; Prestbo and Gay, 2009). In North America seasonal patterns in wet deposition are observed in both depositional flux and concentration with the highest values in the summer and lowest values in the winter (Sorensen et al., 1994; Mason et al., 2000; Guentzel et al., 2001; Keeler et al., 2005; VanArsdale et al., 2005; Choi et al., 2008; Prestbo and Gay, 2009). Explanations for this observation include more effective $\mathrm{Hg}$ scavenging by rain compared to snow (Sorensen et al., 1994; Mason et al., 2000; Keeler et al., 2005; Selin and Jacob, 2008), a greater availability of soluble $\mathrm{Hg}$ due to convective transport in summer events (Guentzel et al., 2001; Keeler et al., 2005), and a summer increase in $\mathrm{Hg}$-containing soil derived particles in the atmosphere (Sorensen et al., 1994).

Geographic differences in $\mathrm{Hg}$ wet deposition may be explained in part by the proximity to atmospheric sources. Results from the National Atmospheric Deposition Program's

Published by Copernicus Publications on behalf of the European Geosciences Union. 
(NADP) Mercury Deposition Network (MDN) sites in the Northeastern United States exhibit a geographic trend with southern and coastal sites receiving higher $\mathrm{Hg}$ concentrations and depositional fluxes (VanArsdale et al., 2005; Prestbo and Gay, 2009). The sites with elevated $\mathrm{Hg}$ deposition are nearer to the East coast megalopolis and downwind of anthropogenic emission sources such as coal burning power plants and waste incinerators. Inconsistent results are reported in studies comparing $\mathrm{Hg}$ wet deposition fluxes and/or concentrations between rural and urban sites. Some report elevated annual fluxes (Mason et al., 2000) and concentrations (Steding and Flegal, 2002; Engle et al., 2010) at urban locations while others report no significant differences in mean concentrations (Sorensen et al., 1994; Guentzel et al., 2001; Hall et al., 2005). Gaseous evasion of $\mathrm{Hg}^{\circ}$ from marine waters is a significant global source of atmospheric $\mathrm{Hg}$ and may also contribute to elevated depositional fluxes in coastal regions (Mason and Sheu, 2002). Holmes et al. (2009) suggest that elevated levels of $\mathrm{Br}$ in the marine boundary layer are important in transforming $\mathrm{Hg}^{\circ}$ to $\mathrm{RGM}$, the more readily deposited gaseous form of $\mathrm{Hg}$.

Like many areas in New England, New Hampshire (NH) air quality is adversely affected by large power plants in the Midwest as well as urban areas located to the south along the East coast of the United States (NHDES, 2004). Two coal combustion power plants are also located in the southern portion of $\mathrm{NH}$ and are likely contributors to the local atmospheric load of Hg. Within the waterways of the Northeastern United States, including NH, biological species have been identified as containing elevated $\mathrm{Hg}$ levels (Chen et al., 2005; Evers et al., 2007) with atmospheric deposition considered the dominant source in undisturbed watersheds (Chen et al., 2005). Three MDN sites were previously located in NH with sample collection lasting from 7 to 16 months and the most recent sampling terminated in 2005. This lack of $\mathrm{Hg}$ wet deposition information was filled using measurements conducted by the AIRMAP program (http://airmap.unh.edu) at the University of New Hampshire (UNH). Event-based wet deposition samples were collected over a 36-month time period from July 2006-August 2009. In this study, seasonal and annual variations of $\mathrm{Hg}$ wet deposition and concentration from a site in Southern NH are compiled and compared to contemporaneous results from MDN sites in the adjacent state of Maine (ME) and data from three MDN sites previously located in New Hampshire. The purpose of this study is to provide an overview of the seasonal $\mathrm{Hg}$ wet deposition patterns at TF, briefly examine meteorological conditions and gas phase indicators of anthropogenic air mass sources in relation to $\mathrm{Hg}$ wet deposition, and compare RGM measurements and estimated RGM dry deposition to $\mathrm{Hg}$ wet deposition.

Event-based precipitation sampling is necessary to elucidate relationships with meteorological and atmospheric chemical conditions. MDN sites predominantly collect weekly samples, not individual event samples. Results in- dicate single weekly samples contribute significantly to the annual Hg load (VanArsdale et al., 2005). Collecting samples over pre-determined time intervals can obscure the contribution of single events and relationships with other factors. An event-based sampling site in Underhill, VT (MDN site VT99) reports discrete precipitation events can contribute between $5-17 \%$ of the total annual wet deposition (Keeler et al., 2005). The event-based sampling at TF provides the opportunity to evaluate relationships between $\mathrm{Hg}$ wet deposition, meteorological conditions and gas phase species.

The more soluble gaseous species, RGM, is thought to be the predominant source of $\mathrm{Hg}$ in wet deposition with minor contributions from washout of $\mathrm{Hg}^{P}$ (Schroeder and Munthe, 1998; Guentzel et al., 2001; Sakata and Asakura, 2007; Kieber et al., 2008). Simultaneous measurements of gas phase $\mathrm{Hg}$ species and wet deposition offer the opportunity for a more thorough understanding of processes affecting $\mathrm{Hg}$ deposition and more accurate estimates of wet and dry deposition. Long-term $\mathrm{Hg}$ wet deposition measurements exist at many locations within the United States and Canada as part of the MDN; however, long-term contemporaneous $\mathrm{Hg}$ gas phase and $\mathrm{Hg}$ wet deposition measurements are lacking (Lindberg et al., 2007; Selin, 2009; Zhang et al., 2009). A recent study (Engle et al., 2010) reports Hg gas phase speciation data, $\operatorname{Hg}^{P}$, and $\mathrm{Hg}$ wet deposition fluxes at nine sites located in the central and eastern United States and Puerto Rico, none of which had data for more than one year. Zhang et al. (2009) provide an overview of the current knowledge regarding the dry deposition of $\mathrm{Hg}$ including $\mathrm{Hg}^{0}, \mathrm{RGM}$, and $\mathrm{Hg}^{P}$. The limited measurement data that are available for RGM deposition have large uncertainties due to the very low ambient concentration and instrument detection limits, the frequent use of surrogate surfaces in measurement techniques, the small vertical gradients in RGM concentration, and the effects of fast chemical reactions and advection from local sources (Zhang et al., 2009). In this study we use automated continuous RGM measurements over a 35-month time period to generate an order of magnitude estimate of the RGM deposition velocity $\left(V_{\mathrm{d}}\right)$ and RGM dry deposition. This is the first multi-year comparison of $\mathrm{Hg}$ wet deposition and RGM and provides insights into seasonal variations in Hg deposition pathways.

\section{Sample collection and analysis}

Precipitation samples were collected at Thompson Farm (TF) $\left(43.11^{\circ} \mathrm{N},-70.95^{\circ} \mathrm{W}, 24 \mathrm{~m}\right.$ elevation) located in Durham, New Hampshire, USA (Fig. 1). The sample site is situated in a rural, residential and agricultural setting immediately surrounded by agricultural fields and mixed hardwood and pine forests. It is approximately $25 \mathrm{~km}$ from the Gulf of Maine and $110 \mathrm{~km}$ north of the city of Boston. The UNH AIRMAP program maintains and collects numerous atmospheric chemistry measurements at TF (Mao and 
Talbot, 2004; Chen et al., 2007; Darby et al., 2007; Mao et al., 2008; Sigler et al., 2009b). Meteorological data used in this study (temperature, solar radiation, precipitation amount) are from the NOAA Climate Reference Network (CRN) site co-located at TF. Information about CRN data measurement and collection techniques is available at http://www.ncdc.noaa.gov/crn/instrdoc.html.

Wet deposition samples were collected using a modified Aerochem automated precipitation sampler, identical to samplers used in the MDN. Sample collection bottles were manually changed on a primarily event-based schedule. Trace metal sampling techniques were followed in accordance with EPA method 1669. The sampling train consisted of acid washed polyethylene funnels placed directly into preacidified and acid washed fluorinated ethylene propylene (FEP) bottles. Prior to sample deployment, bottle blanks were collected and sample bottles were treated with $1.25 \mathrm{~mL}$ of $6 \mathrm{~N} \mathrm{HCl}$ for sample preservation.

Upon collection, samples were preserved in the original collection bottle with the addition of trace metal grade hydrochloric acid and bromine monochloride to a final concentration of $0.5 \%$. Samples were analyzed with a Tekran model 2600 dual amalgamation cold vapor atomic fluorescence spectrometer following a modified version of EPA method 1631 recommended in the Tekran user's guide. The average system blank value over all sample analyses was $0.45 \mathrm{ng}^{-1}$ and the average method detection limit was $0.08 \mathrm{ng}^{-1}$ as determined by three times the standard deviation of the system blank. The average bottle blank abundance was $0.09 \mathrm{ng}$. ORMS-3 and ORMS-4 (National Research Council, Canada) were used as external standards and results were within range of the accepted values. Final concentration values were corrected for system and bottle blanks. Precipitation samples with a collected volume of less than $20 \mathrm{ml}$ are excluded from this data set $(n=21)$. The $\mathrm{Hg}$ wet deposition data discussed in this study include 162 wet-only samples collected from 21 July 2006 to 30 August 2009.

RGM has been measured at TF since November 2006 using a $\mathrm{KCl}$-coated denuder module attached to a cold vapor atomic florescence spectrometer (Tekran model 2537A; for details see Sigler et al., 2009b). The RGM sampling interval was $2 \mathrm{~h}$ followed by a $30 \mathrm{~min}$ flush with zero air and heating cycle to desorb the RGM and allow for quantification as $\mathrm{Hg}^{0}$ by the Tekran 2537A unit. Due to the addition of in-line $\mathrm{Hg}^{P}$ measurements in February 2009, the desorption interval increased to $60 \mathrm{~min}$. Following this change the zero flushes showed no evidence of contamination, and there were no significant differences in $\mathrm{Hg}^{0}$ and RGM levels. The limit of detection for RGM determined from three times the standard deviation of the average blank was approximately 0.1 ppqv.

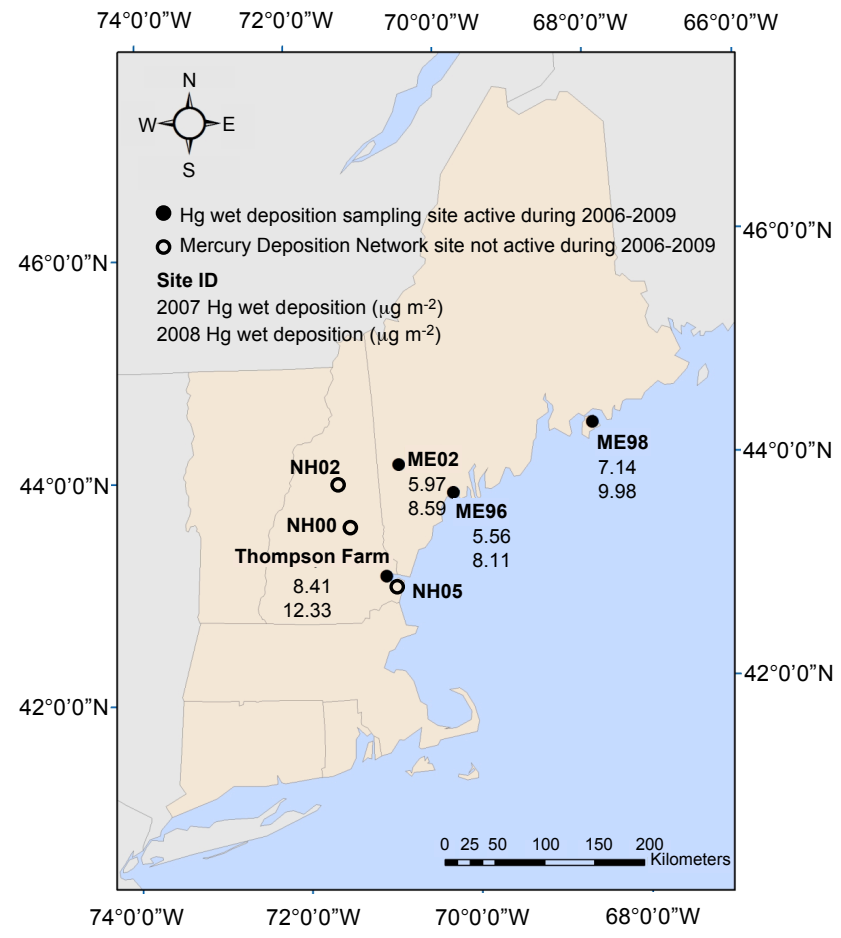

Fig. 1. Thompson Farm location and Mercury Deposition Network locations in Maine and New Hampshire.

\section{Hg wet deposition seasonal patterns and inter-annual variability}

Wet-only samples were collected at TF from 21 July 2006 to 30 August 2009 and represent 260 precipitation events. In this study, we define a precipitation event as a period of precipitation bordered by a twelve-hour time interval of no precipitation. An in-depth analysis of the meteorological conditions resulting in precipitation was not conducted as part of this study, therefore the potential exists that our definition of an event could include the passage of two different storm fronts within $12 \mathrm{~h}$ of each other. Ninety-seven samples (60\%) represent single events and 45 samples (28\%) represent two precipitation events. Figure $2 \mathrm{a}-\mathrm{c}$ shows the measured concentration, calculated deposition, and total precipitation for each sample in the study period. The maximum $\mathrm{Hg}$ concentration was $65.09 \mathrm{ng}^{-1}$ occurring on 12 July 2007. The maximum single event deposition was $1.74 \mu \mathrm{g} \mathrm{m}^{-2}$ and occurred from 23 July to 24 July 2008 . This single precipitation event constituted almost $6 \%$ of the total wet deposition at TF during this three-year study and $14 \%$ of the annual load for 2008. As shown in Fig. 2b, single precipitation events with elevated $\mathrm{Hg}$ deposition levels can account for a substantial portion of the total deposition. Similarly, Keeler et al. (2005) also report a single event contributing approximately $17 \%$ to the annual $\mathrm{Hg}$ wet deposition load from event-based sampling in Underhill, VT. 
Table 1. Seasonal and annual total precipitation, $\mathrm{Hg}$ wet deposition, and concentration summary statistics for Thompson Farm. Spring and summer are shaded for easier visual comparison by season.

\begin{tabular}{|c|c|c|c|c|c|c|c|c|c|}
\hline Season & $\begin{array}{l}\text { Precipitation } \\
\text { total }(\mathrm{cm})\end{array}$ & \multicolumn{4}{|c|}{ Deposition $\left(\mu \mathrm{g} \mathrm{m}^{-2}\right)$} & \multicolumn{3}{|c|}{ Concentration $\left(\mathrm{ng} \mathrm{l}^{-1}\right)$} & $\begin{array}{l}\text { VWM concentration } \\
\left(\mathrm{ng} 1^{-1}\right)\end{array}$ \\
\hline $21 \mathrm{Jul} 2006$ to $20 \mathrm{Sep} 2006$ & 22.46 & 1.16 & 0.116 & 0.089 & $0.027-0.263$ & 6.16 & 5.05 & $1.39-12.51$ & 5.23 \\
\hline Winter 2006-2007 & 24.58 & 1.12 & 0.125 & 0.121 & $0.016-0.274$ & 10.50 & 5.90 & $0.96-47.50$ & 4.76 \\
\hline Spring 2007 & 40.13 & 3.39 & 0.339 & 0.379 & $0.030-0.561$ & 18.14 & 10.57 & $0.99-47.89$ & 8.69 \\
\hline Summer 2007 & 20.59 & 3.02 & 0.275 & 0.234 & $0.090-0.548$ & 22.84 & 14.24 & $4.24-65.09$ & 14.85 \\
\hline Spring 2008 & 19.97 & 1.79 & 0.162 & 0.107 & $0.066-0.553$ & 12.49 & 8.64 & $3.48-25.81$ & 8.84 \\
\hline Summer 2008 & 52.52 & 6.37 & 0.354 & 0.112 & $0.015-1.737$ & 15.29 & 14.74 & $4.21-37.72$ & 12.48 \\
\hline Fall 2008 & 37.00 & 1.76 & 0.125 & 0.114 & $0.039-0.256$ & 7.55 & 6.77 & $2.24-19.21$ & 4.60 \\
\hline Winter 2008-2009 & 29.86 & 1.49 & 0.149 & 0.133 & $0.050-0.339$ & 9.04 & 4.50 & $2.72-34.83$ & 5.67 \\
\hline Spring 2009 & 27.37 & 2.23 & 0.172 & 0.137 & $0.020-0.452$ & 9.52 & 7.86 & $3.57-17.76$ & 8.18 \\
\hline 21 Jun 2009 to 30 Aug 2009 & 37.36 & 2.62 & 0.202 & 0.168 & $0.042-0.565$ & 9.94 & 9.70 & $3.34-20.62$ & 7.02 \\
\hline Year 2007 & 114.1 & 8.41 & 0.205 & 0.155 & $0.016-0.561$ & 13.68 & 6.88 & $0.75-65.09$ & 7.97 \\
\hline Year 2008 & 160.3 & 12.33 & 0.209 & 0.115 & $0.015-1.74$ & 10.41 & 8.41 & $1.66-37.72$ & 8.09 \\
\hline
\end{tabular}

During the 37-month sampling period at TF, the cumulative $\mathrm{Hg}$ wet deposition was $30.78 \mu \mathrm{g} \mathrm{m}^{-2}$ and the total precipitation depth was $4.28 \mathrm{~m}$. The seasonal and annual variations in $\mathrm{Hg}$ concentration and wet deposition are summarized in Table 1. In this study, seasons are delineated according to the calendar definition. In general, the summer and spring exhibited elevated Hg concentrations and wet deposition with an unusually large wet deposition value in summer 2008.

The seasonal volume weighted mean (VWM) concentrations of $\mathrm{Hg}$ in precipitation at $\mathrm{TF}$ are shown in Fig. 3a and listed in Table 1. The VWM concentrations are elevated during the spring and summer seasons in comparison to the fall and winter seasons. These seasonal variations in VWM Hg concentrations are annually repeatable. The greatest seasonal VWM Hg concentrations at TF occurred in both summer seasons (summer $2007=14.85 \mathrm{ng} \mathrm{l}^{-1}$; summer $2008=12.48 \mathrm{ngl}^{-1}$ ), with the second highest seasonal concentrations occurring in the spring seasons of each year. The summer VWM Hg concentrations are 2.2-3.4 times greater than the fall and winter values. There is little variability in the VWM concentrations at TF for the same season from year-to-year. These seasonal variations are similar to previously reported patterns at MDN sites within northeastern North America (Keeler et al., 2005; VanArsdale et al., 2005; Prestbo and Gay, 2009).

Total seasonal Hg wet deposition at TF is shown in Fig. 3b and listed in Table 1. The Hg wet deposition is calculated as the product of the event concentration and amount of precipitation (Fig. 3c). Patterns in seasonal $\mathrm{Hg}$ wet deposition are less consistent than the VWM concentrations and are linked more closely to precipitation totals. In 2007 the highest seasonal deposition, $3.39 \mu \mathrm{g} \mathrm{m}^{-2}$, occurred in the spring, while in 2008 it was observed in the summer with a value of $6.39 \mu \mathrm{g} \mathrm{m}^{-2}$. The large deposition in summer $2008 \mathrm{re-}$ flects the combination of typically greater summer $\mathrm{Hg}$ concentrations and the above normal precipitation for that season (Fig. 3c). The total amount of precipitation received in summer 2008 was $180 \%$ above the 30 -year summer average in New Hampshire (http://www.nrcc.cornell.edu). Similarly, the elevated deposition at TF during the 2007-2008 winter, compared to other winters, is most likely due to the elevated amount of precipitation, which was $154 \%$ above the 30 year winter average (http://www.nrcc.cornell.edu).

Annual $\mathrm{Hg}$ wet deposition varied over the duration of this study and was strongly linked to annual precipitation totals. During the calendar years 2007 and 2008 the $\mathrm{Hg}$ wet deposition at $\mathrm{TF}$ was $8.41 \mu \mathrm{g} \mathrm{m}^{-2} \mathrm{yr}^{-1}$ and $12.33 \mathrm{\mu g} \mathrm{m}^{-2} \mathrm{yr}^{-1}$, respectively with corresponding precipitation totals of $114.1 \mathrm{~cm}$ and $160.3 \mathrm{~cm}$. During this two year interval the amount of precipitation increased by $40 \%$ and the annual $\mathrm{Hg}$ wet deposition increased by $47 \%$. These increases are similar in magnitude, indicating that the large annual $\mathrm{Hg}$ wet deposition for 2008 is primarily a consequence of enhanced precipitation. The amount of precipitation in New Hampshire during 2008 was $43 \%$ above the 30 year normal and the highest annual amount of precipitation based on a 114-year record (http://www.nrcc.cornell.edu). In contrast, the amount of precipitation at TF during 2007 was only $11 \%$ above the normal. To put the annual $\mathrm{Hg}$ wet deposition in context, the typical annual fluxes reported for MDN sites in the northeastern United States (NY, NJ, and New England) and eastern Canada from 1996-2005 were 4-8 $\mathrm{gg} \mathrm{m}^{-2} \mathrm{yr}^{-1}$ (Prestbo and Gay, 2009). The $\mathrm{Hg}$ annual wet deposition at TF for 2007 is slightly above this range, whereas the annual deposition for 2008 is $>50 \%$ higher. This comparison in 

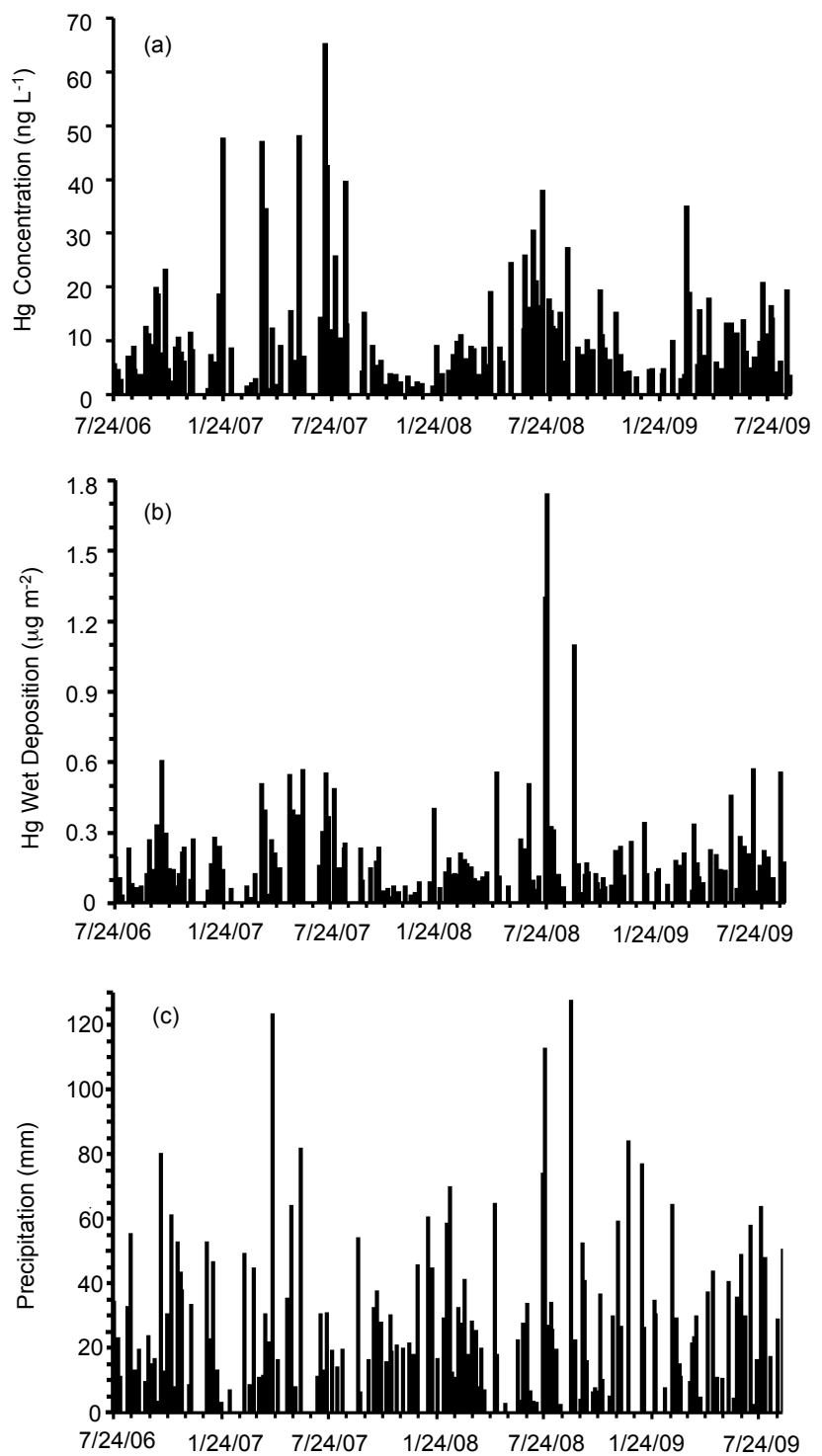

Fig. 2. Time series of wet deposition samples from Thompson Farm; (a) $\mathrm{Hg}$ concentration, (b) $\mathrm{Hg}$ wet deposition, (c) precipitation amount.

annual $\mathrm{Hg}$ wet deposition is made to emphasize the elevated deposition measured at TF during 2008. Comparisons between different time periods and locations should be made with caution due to the varying conditions such as the proximity and output of emission sources that may affect deposition and change with time and location.

\section{Comparison with MDN sites}

The wet only results from TF are compared to samples collected during the same time period at MDN sites located in Maine (Fig. 3a-c) (NADP/MDN, 2001-2009). These MDN sites were chosen for comparative purposes due to their prox-
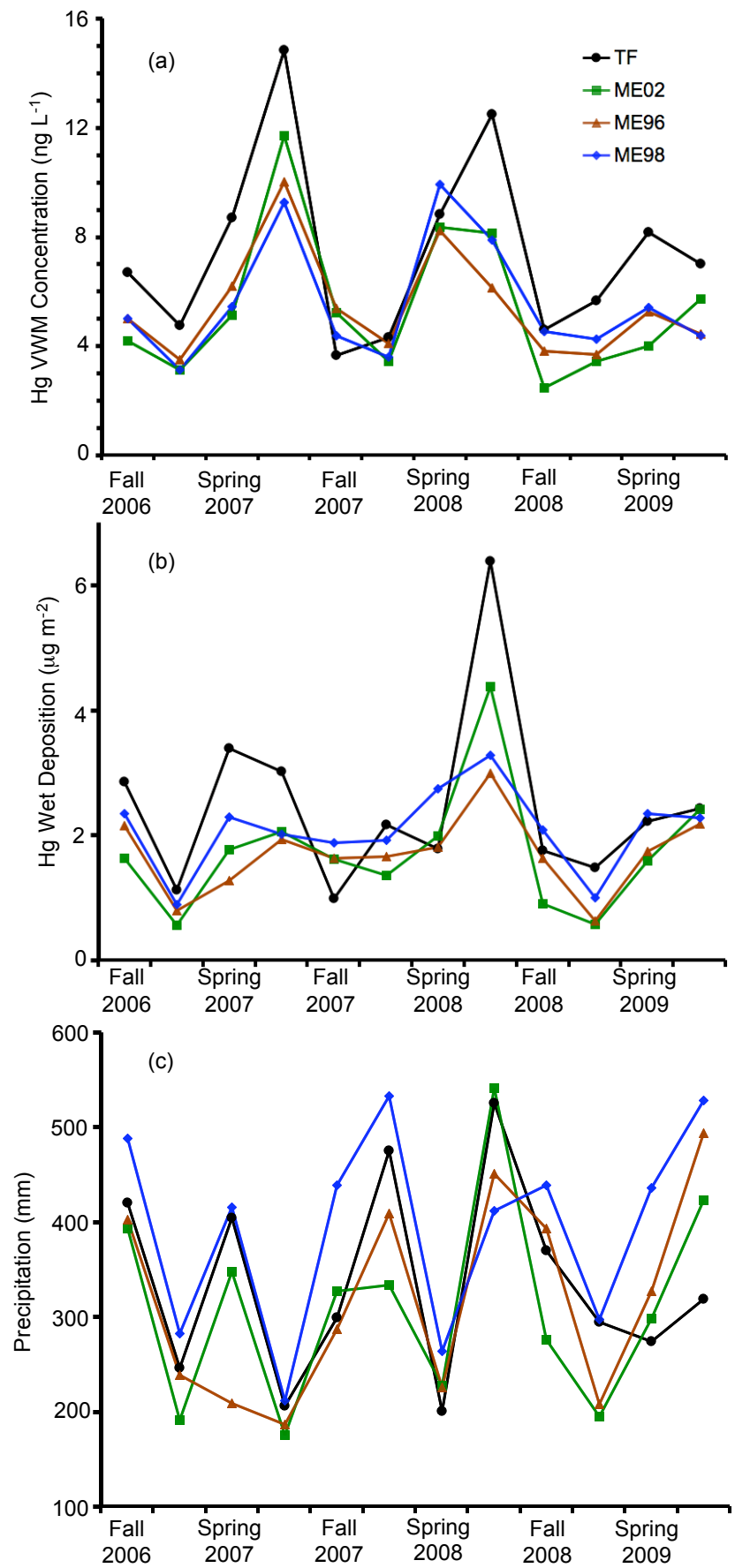

Fig. 3. Seasonal $\mathrm{Hg}$ volume weighted mean concentrations (a), $\mathrm{Hg}$ wet deposition (b), and precipitation amount (c), at Thompson Farm and Mercury Deposition Network sites located in Maine.

imity to TF, the coastal locations of ME96 and ME98 and locations downwind of the city of Boston. Patterns in seasonal VWM concentrations and $\mathrm{Hg}$ wet deposition are generally consistent between TF and the Maine MDN sites (Fig. 3a and $b$ ) with elevated levels during spring and summer seasons. The greatest seasonal VWM concentration during this 
Table 2. Kendall's $\tau$ correlation co-efficients for $\mathrm{Hg}$ wet deposition and $\mathrm{Hg}$ concentration with meteorological conditions and gas phase measurements at Thompson Farm. Asterisks indicate $p<0.05$.

\begin{tabular}{lrr}
\hline & $\begin{array}{r}\text { Hg wet } \\
\text { deposition }\end{array}$ & $\begin{array}{r}\mathrm{Hg} \\
\tau\end{array}$ \\
& $\tau$ & $\tau$ \\
\hline Daily average temperature & 0.07 & $0.23^{*}$ \\
Daily total solar radiation & -0.02 & $0.29^{*}$ \\
Daily average CO & -0.01 & 0.00 \\
Daily average NOy & -0.09 & -0.11 \\
Daily maximum RGM & 0.07 & 0.09 \\
RGM depletion during pre- & 0.10 & -0.02 \\
cipitation event & & \\
\hline
\end{tabular}

sampling period occurred at all locations for summer 2007. The 2006-2007 winter had the lowest seasonal VWM Hg concentration at TF and all Maine MDN sites with the exception of ME02. Similarly, all sites had the highest total seasonal $\mathrm{Hg}$ wet deposition in summer 2008 and low wet deposition totals during the winter seasons.

The seasonal VWM Hg concentrations and seasonal wet deposition at TF are typically greater than the Maine MDN sites (Fig. $3 a$ and $b$ ), possibly due to a combination of elevated $\mathrm{Hg}$ concentrations and precipitation. $\mathrm{TF}$ is the most southerly of the sites resulting in slightly warmer temperatures compared to the MDN sites and is also located nearer large urban pollution sources such as Boston and New York City. Mao and Talbot (2004) indicate TF can be influenced by transport of polluted air masses from the Boston and MidAtlantic States region. Thus it is reasonable to hypothesize that TF receives more $\mathrm{Hg}$ due to the proximity of anthropogenic emissions. Also the amount of precipitation recorded at TF is consistently second highest amongst these sites with MDN site ME98 regularly receiving the most precipitation. In-depth studies are warranted to understand the causes for such geographic differences in $\mathrm{Hg}$ wet deposition.

For an historical perspective, results from this study are briefly compared to the three MDN sites previously located in New Hampshire (Fig. 1) (NADP/MDN, 2001-2009). The only historical site with results for four complete seasons is NH05 with data available from March 2001 to June 2002. At NH05, summer 2001 had the highest VWM concentration $\left(11.51 \mathrm{ng}^{-1}\right)$ and spring 2002 had the greatest seasonal $\mathrm{Hg}$ deposition and precipitation totaling $2.59 \mu \mathrm{g} \mathrm{m}^{-2}$ and $37.3 \mathrm{~cm}$, respectively. $\mathrm{Hg}$ wet deposition data is available for NH02 from February 2004 to February 2005. For the seasons with complete data available, spring 2004 had the highest VWM Hg concentration (9.02 $\mathrm{ng} \mathrm{l}^{-1}$ ). Summer 2004 had the greatest wet deposition and precipitation totaling $3.47 \mu \mathrm{g} \mathrm{m}^{-2}$ and $46.3 \mathrm{~cm}$, respectively. At NHOO data are only available for seven months from May 2001 through De- cember 2001. The summer had greater $\mathrm{Hg}$ wet deposition and VWM concentration than the fall. The seasonal variations in the data collected from the MDN sites previously located in $\mathrm{NH}$ are consistent with our findings at TF. The spring and summer have elevated VWM concentrations and $\mathrm{Hg}$ wet deposition in comparison to the fall and winter.

\section{Influence of meteorological conditions and other trace gases on $\mathrm{Hg}$ wet deposition}

Relationships were examined between $\mathrm{Hg}$ wet deposition, $\mathrm{Hg}$ concentration, and meteorological parameters including temperature and solar radiation at the TF site. Nonparametric Kendall's $\tau$ was calculated to determine correlations between these parameters. Only precipitation samples representative of single events are included in this analysis. Table 2 summarizes these statistical results.

Previous studies attribute regional and seasonal differences in $\mathrm{Hg}$ wet deposition to temperature differences (Keeler et al., 2005). On an event basis there is weak correlation between the average daily temperature and $\mathrm{Hg}$ concentration $(\tau=0.23, p<0.05)$. The correlation between average daily temperature and $\mathrm{Hg}$ wet deposition is very minor and not statistically significant. Additionally, studies suggest photochemistry is important in the production of RGM (Lin and Pehkonen, 1999; Sigler et al., 2009b) implying a relationship with $\mathrm{Hg}$ wet deposition (Selin and Jacob, 2008). In this study we looked into relationships between solar radiation and $\mathrm{Hg}$ wet deposition. At TF, $\mathrm{Hg}$ concentration is correlated with total daily solar radiation $(\tau=0.29, p<0.05)$. The lack of strong correlations on an event basis between temperature, solar radiation and $\mathrm{Hg}$ wet deposition and concentrations indicates that effects from these parameters are not directly related to $\mathrm{Hg}$ wet deposition.

To investigate anthropogenic contributions to $\mathrm{Hg}$ wet deposition, we examined links with $\mathrm{Hg}$ wet deposition and gas phase concentrations of carbon monoxide (CO), and total reactive nitrogen $\left(\mathrm{NO}_{\mathrm{y}}\right)$, commonly used indicators for anthropogenic influence (Mao et al., 2008). CO is emitted mainly from mobile combustion sources while $\mathrm{NO}_{\mathrm{y}}$ includes compounds emitted directly from fossil-fuel combustion and oxidation products of such compounds. This initial investigation of relationships between $\mathrm{CO}, \mathrm{NO}_{\mathrm{y}}$, and $\mathrm{Hg}$ concentration in precipitation and wet deposition does not suggest strong or statistically significant correlations $(p<0.05)$. An in-depth analysis of individual events with identified air mass source regions may provide more information on the lack of influence of these trace gases on $\mathrm{Hg}$ wet deposition.

\section{Linkage between RGM and Hg wet deposition}

RGM is more soluble than $\mathrm{Hg}^{\circ}$ and therefore important in contributing to both the wet and dry deposition of $\mathrm{Hg}$ (Schroeder and Munthe, 1998; Selin, 2009). However, few 
studies report long-term concurrent measurements of RGM and $\mathrm{Hg}$ wet deposition (Engle et al., 2010). RGM has been measured at TF (Sigler et al., 2009b; Mao et al., 2011) and we compare these measurements with $\mathrm{Hg}$ wet deposition measurements during the nearly three-year period from November 2006 through August 2009.

Elevated RGM mixing ratios typically occur in winter and spring at TF (Fig. 4), and the typical diurnal cycle for RGM is a minimum at night with a rapid increase during the morning to peak levels at midday (Sigler et al., 2009b; Mao et al., 2011). Based on relationships of RGM with trace gases such as $\mathrm{CO}, \mathrm{CO}_{2}$, and $\mathrm{SO}_{2}$, and meteorological conditions at $\mathrm{TF}$, Sigler et al. (2009a, b) suggest the elevated RGM mixing ratios during winter months may be due to local emissions from heating sources and slower RGM removal processes. The elevated spring RGM mixing ratios at TF are attributed to photochemical production and high biogenic emissions of $\mathrm{Hg}^{\circ}$.

\section{Scavenging of RGM during precipitation events}

RGM mixing ratios typically decline during precipitation events at TF. Sigler et al. (2009a, b) and Mao and Talbot (2011) observed RGM depletion during precipitation events at this site and others have made similar observations at diverse locations (Lindberg and Stratton, 1998; Yatavelli et al., 2006; Laurier and Mason, 2007). Despite this indication of RGM scavenging during precipitation events at TF, correlations between $\mathrm{Hg}$ wet deposition and $\mathrm{Hg}$ concentration in precipitation versus daily maximum RGM and RGM depletion during precipitation events were not statistically significant (Table 2). Our results demonstrate an indirect relationship between seasonal surface level RGM mixing ratios and total aqueous $\mathrm{Hg}$ in wet deposition. RGM mixing ratios are greatest during the winter, yet $\mathrm{Hg}$ concentrations in precipitation and wet deposition are lowest during the winter. Possible explanations for the low $\mathrm{Hg}$ wet deposition in winter are the underestimation of wet deposition due to inefficient snow collection and/or less effective scavenging of RGM by snow.

A comparison between the collected sample volume and precipitation amount reveals that lower sampling efficiencies occur most frequently during winter precipitation events. Based on the surface area of the funnel used in our sampling train, $1 \mathrm{~mm}$ of precipitation should result in $12 \mathrm{ml}$ of collected sample. A linear regression between the actual amount of sample collected and amount of precipitation during the non-winter seasons at TF reveals the same result (i.e. $1 \mathrm{ml}$ of precipitation $\sim 12 \mathrm{ml}$ of sample, $r^{2}=0.99$ ). Not all winter precipitation events are under sampled, however 13 of a total 16 precipitation events with a sampling efficiency of less than $80 \%$ occur during the winter. It is not known how the inefficient collection of snow affects the measured $\mathrm{Hg}$ concentration at TF, however based on a limited study at a nearby MDN site, we infer the lower sampling efficiency may result in low Hg concentrations. Nelson et al. (2008) compare

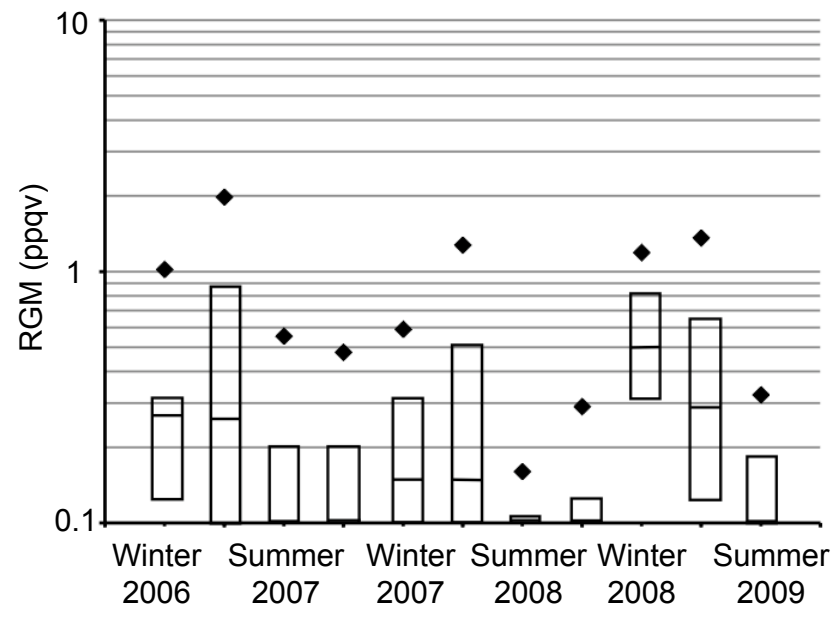

Fig. 4. Seasonal variations in RGM at TF. Each box encompasses the 25 th to 75 th percentiles and the solid horizontal line within each box represents the median value. The black diamonds indicate the 90th percentile.

event-based snow sampling techniques at MDN site ME98. Their results show greater snow water equivalents (i.e. collection efficiency) and $\mathrm{Hg}$ snowfall concentrations in samples collected using a collection method different than the MDN.

In this study, ineffective scavenging of RGM by snow is evidenced by the less frequent depletion of RGM below the limit of detection (LOD, $0.1 \mathrm{ppqv}$ ) during winter precipitation events at TF. Seven of 19 winter precipitation events (37\%) result in RGM mixing ratios below the LOD. RGM mixing ratios during summer precipitation events dip below the LOD at a much higher frequency; 17 of 20 events (85\%). These seasonal variations in RGM removal efficiencies substantiate the hypothesis that seasonal variations in $\mathrm{Hg}$ wet deposition are due in part to less effective scavenging of gas phase $\mathrm{Hg}$ by snow (Keeler et al., 2005; Selin and Jacob, 2008).

\section{Estimation of RGM dry deposition}

It is important to gauge the relative contribution of $\mathrm{Hg}$ wet deposition in comparison with other atmospheric $\mathrm{Hg}$ sinks such as RGM dry deposition. To accomplish this we performed an order-of-magnitude estimate for RGM dry deposition using long-term continuous measurements of RGM mixing ratios. Estimates of RGM dry deposition velocity and deposition at TF were calculated based on nighttime depletion events, which are most common during warm season (May to September) nocturnal inversions in the planetary boundary layer. The method has been employed in Talbot et al. (2005), Mao et al. (2008), and Sigler et al. (2009b), and the step-by-step estimate is elucidated in Russo et al. (2010). A brief explanation of this method is given here. Nocturnal 


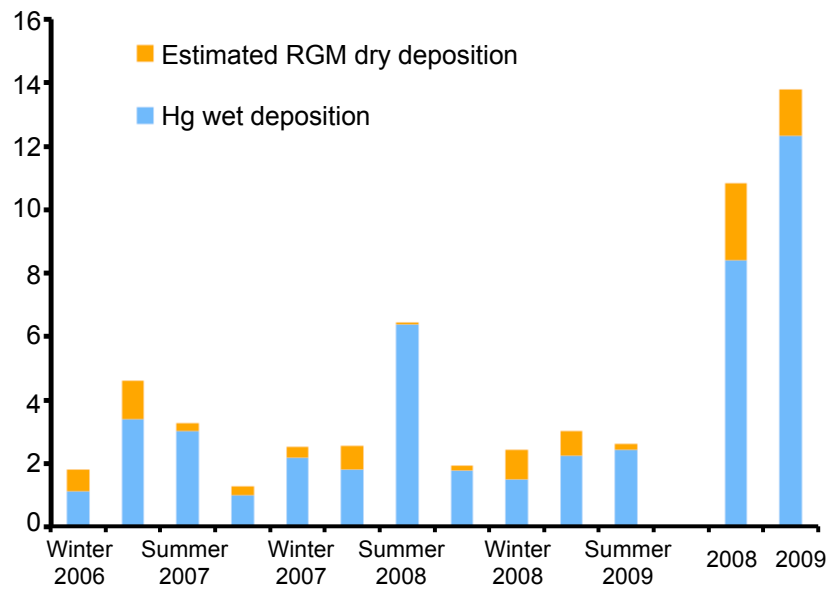

Fig. 5. Seasonal and annual $\mathrm{Hg}$ wet deposition and estimated RGM dry deposition at TF.

inversions at TF are evidenced by the depletion ( $<5 \mathrm{ppbv})$ of atmospheric ozone and $\mathrm{Hg}^{\circ}$ (Mao et al., 2008). Concurrent depletions were also observed in RGM. To obtain a robust estimate we used the diurnal cycle average over all days from the warm season with the occurrence of nocturnal inversions. The average rates of RGM depletion and RGM concentration during these inversions were calculated to solve for the deposition velocity in the following equation:

$V_{\mathrm{d}}=\frac{d C}{d t} \cdot \frac{H}{\bar{C}}$

where $V_{\mathrm{d}}$ is the deposition velocity, $d C / d t$ is the rate of change in RGM concentration from the average diurnal cycle in RGM over all inversion events, $\bar{C}$ is the average RGM concentration over the depletion period, and $\mathrm{H}$ is the boundary layer height. In these calculations a constant boundary layer height of $125 \mathrm{~m}$ is applied (Talbot et al., 2005; Mao et al., 2008; Russo et al., 2010). This calculation also assumes that during the nocturnal inversions dry deposition is the only loss mechanism of RGM and there is no RGM production, therefore the calculated $V_{\mathrm{d}}$ should be considered a maximum due to the potential for RGM loss due to aerosol uptake.

Nocturnal inversion events were identified by the nighttime depletion of ozone to less than $5 \mathrm{ppbv}$ with a corresponding decrease in RGM to less than $0.1 \mathrm{ppqv}$. The number of inversion events per warm season varied from 17 to 21 during 2007 to 2009. The average RGM concentration over the depletion period varied annually from 0.13 to $0.20 \mathrm{ppqv}$ however, the RGM depletion based on the average diurnal cycle was always complete in the time window of 00:00 to 03:00 UTC. Using Eq. (1) the average RGM dry deposition velocity at TF is estimated to be $2.31 \mathrm{~cm} \mathrm{~s}^{-1}$. This estimate is within the range of RGM dry deposition velocities reported in the literature $\left(0.5\right.$ to $\left.7.6 \mathrm{~cm} \mathrm{~s}^{-1}\right)$ from a variety of measurement methods, surface compositions, locations, and seasons (Zhang et al., 2009, and references therein).

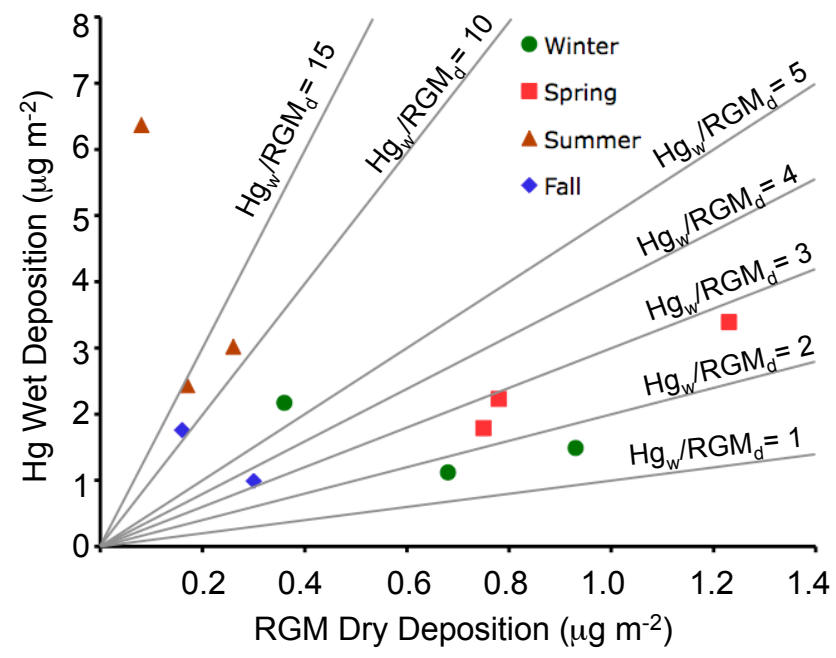

Fig. 6. Seasonal Hg wet deposition fluxes and estimated R GM dry deposition fluxes at TF. Contour lines represent wet to dry deposition $\left(\mathrm{Hg}_{\mathrm{w}} / \mathrm{RGM}_{\mathrm{d}}\right)$ ratios.

RGM dry deposition at TF was estimated using measured RGM mixing ratios and a dry deposition velocity of $2.31 \mathrm{~cm} \mathrm{~s}^{-1}$. The seasonal and annual estimated RGM dry deposition and comparison to $\mathrm{Hg}$ wet deposition is shown in Fig. 5. There is distinct variation in seasonal dry deposition of RGM. The greatest seasonal RGM dry deposition $\left(>0.6 \mu \mathrm{g} \mathrm{m}^{-2}\right.$ ) occurs in the winter and spring (excluding winter 2007), following the seasonal pattern in RGM mixing ratios. Summer and fall exhibit low RGM dry deposition values, all below $0.4 \mu \mathrm{g} \mathrm{m}^{-2}$ (Fig. 6).

\section{Comparison between RGM dry deposition and $\mathrm{Hg}$ wet deposition}

Estimated RGM dry deposition is less than the measured $\mathrm{Hg}$ wet deposition for all seasons and on an annual basis (Table 3 and Fig. 5). Our results suggest that the relative contribution of $\mathrm{Hg}$ wet deposition and RGM dry deposition to the total $\mathrm{Hg}$ deposition flux at TF varies greatly by season and is opposite in phase with ratios of $\mathrm{Hg}$ wet deposition to RGM dry deposition ranging from 1.6 in the winter to 80 during summer 2008 (Fig. 6). Large Hg wet deposition and low RGM dry deposition typically occurs in summer. The greatest ratio occurred in summer 2008 reflecting the exceptionally large amount of precipitation and $\mathrm{Hg}$ wet deposition and the lowest RGM dry deposition estimate of all summers. On an annual basis the ratios of $\mathrm{Hg}$ wet deposition to RGM dry deposition are moderate in comparison to the large seasonal variations at TF. The ratio for annual year 2008 is more than double the ratio for 2007 (8.5 and 3.5, respectively) and the large ratio likely reflects the record amount of precipitation in 2008 .

We can compare our calculations to only a few studies from the literature reporting both $\mathrm{Hg}$ wet deposition 
Table 3. Seasonal and annual $\mathrm{Hg}$ wet deposition and estimated RGM dry deposition fluxes, and the sum of $\mathrm{Hg}$ wet deposition and estimated RGM dry deposition at TF. The asterisks indicate seasons missing more than 3 days of RGM measurements. The seasonal daily average RGM was used to fill gaps in the data and calculate a total RGM flux. Spring and summer are shaded for easier visual comparison by season.

\begin{tabular}{lccc}
\hline Season & $\begin{array}{c}\text { Hg wet deposition } \\
\left(\mu \mathrm{g} \mathrm{m}^{-2}\right)\end{array}$ & $\begin{array}{c}\text { RGM dry deposition } \\
\left(\mu \mathrm{g} \mathrm{m}^{-2}\right)\end{array}$ & $\begin{array}{c}\text { Wet plus RGM dry deposition } \\
\left.\mu \mathrm{g} \mathrm{m}^{-2}\right)\end{array}$ \\
\hline Winter 2006-2007 & 1.12 & 0.68 & 1.80 \\
Spring 2007 & 3.39 & 1.23 & 4.62 \\
Summer 2007 & 3.02 & 0.26 & 3.28 \\
Fall 2007 & 0.99 & 0.30 & 1.29 \\
Winter 2007-2008 & 2.17 & 0.36 & 2.53 \\
Spring 2008 & 1.79 & 0.75 & 2.54 \\
Summer 2008 & 6.37 & $0.08^{*}$ & 6.45 \\
Fall 2008 & 1.76 & $0.16^{*}$ & 1.92 \\
Winter 2008-2009 & 1.49 & $0.93^{*}$ & 2.42 \\
Spring 2009 & 2.23 & 0.78 & 3.01 \\
21 Jun 2009 to 30 Aug 2009 & 2.44 & 0.17 & 2.61 \\
Year 2007 & 8.41 & 2.43 & 10.84 \\
Year 2008 & 12.33 & 1.45 & 13.78 \\
\hline
\end{tabular}

Table 4. A comparison between annual $\mathrm{Hg}$ wet deposition and RGM dry deposition values reported in the literature and calculated in this study. Hg wet deposition to RGM dry deposition ratios are calculated from data provided in Engle et al. (2010) and Miller et al. (2005).

\begin{tabular}{llcccl}
\hline Location & Dates & $\begin{array}{c}\text { Hg wet deposition } \\
\left(\mu \mathrm{g} \mathrm{m}^{-2} \mathrm{yr}^{-1}\right)\end{array}$ & $\begin{array}{c}\text { RGM dry deposition } \\
\left(\mu \mathrm{g} \mathrm{m}^{-2} \mathrm{yr}^{-1}\right)\end{array}$ & $\begin{array}{c}\mathrm{Hg} \text { wet dep./ } \\
\text { RGM dry dep. }\end{array}$ & Reference \\
\hline Alabama & 12 Apr 2005-11 Apr 2006 & 10.9 & 2.2 & 4.95 & Engle et al. (2010) \\
Illinois & 1 Jan 2004-31 Dec 2004 & 11.0 & 51.8 & 0.21 & Engle et al. (2010) \\
Massachusetts & 5 Feb 2008-3 Feb 2009 & 2.9 & 1.0 & 2.9 & Engle et al. (2010) \\
New Hampshire & None given & 5.8 & 7.5 & 0.77 & Miller et al. (2005) \\
New Hampshire & 1 Jan 2007-31 Dec 2007 & 8.41 & 2.43 & 3.46 & This study \\
New Hampshire & 1 Jan 2008-31 Dec 2008 & 12.33 & 1.45 & 8.50 & This study \\
North Dakota & 1 Jan 2004-12 Dec 2004 & 3.3 & 1.7 & 1.94 & Engle et al. (2010) \\
Puerto Rico & 1 Jan 2006-31 Dec 2006 & 29.5 & 0.5 & 59 & Engle et al. (2010) \\
South Carolina & 23 May 2006-22 May 2007 & 6.5 & 1.8 & 3.61 & Engle et al. (2010) \\
Virginia & 1 Jan 2006-12 Dec 2006 & 9.0 & 1.4 & 6.43 & Engle et al. (2010) \\
Wisconsin & 28 Jun 2004-6 Jun 2005 & 6.7 & 5.3 & 1.26 & Engle et al. (2010) \\
\hline
\end{tabular}

and RGM dry deposition (Table 4). Published comparisons of $\mathrm{Hg}$ wet deposition to total $\mathrm{Hg}$ dry deposition $\left(\mathrm{Hg}^{\circ}+\mathrm{RGM}+\mathrm{Hg}^{P}\right)$ in New Hampshire are based on modeled results (Miller et al., 2005; Han et al., 2008). Miller et al. (2005) estimate a total $\mathrm{Hg}$ flux of $21.1 \mu \mathrm{g} \mathrm{m}^{-2} \mathrm{y}^{-1}$ in New Hampshire with approximately equal contributions of 7.4 and $7.5 \mu \mathrm{g} \mathrm{m}^{-2} \mathrm{y}^{-1}$, respectively, from $\mathrm{Hg}^{0}$ and RGM dry deposition followed by a wet deposition contribution of $5.8 \mu \mathrm{g} \mathrm{m}^{-2} \mathrm{y}^{-1}$. Minor contributions are attributed to $\mathrm{Hg}^{P}$ and cloud water at 0.38 and $0.058 \mu \mathrm{g} \mathrm{m}^{-2} \mathrm{y}^{-1}$, respectively. Miller et al. (2005) state that their RGM estimates should be considered within the correct order magnitude but they have low confidence in the exact value due to the lack of measurement data for comparison. Han et al. (2008) simulated the total atmospheric deposition of RGM plus $\mathrm{Hg}^{P}$ in New Hampshire for the years 1996, 1999, and 2002 based on $\mathrm{Hg}$ emission inventories for the state and adjacent areas. Their ratios of annual wet to dry RGM plus $\mathrm{Hg}^{P}$ deposition range from 1.01 to 0.57 . RGM deposition ranges from a factor of 6 to 21 times greater than $\mathrm{Hg}^{P}$ deposition. The model used by Han et al. (2008) only considers $\mathrm{Hg}$ from local emission sources and does not account for regional and global sources of $\mathrm{Hg}$ or atmospheric reactions.

Annual ratios of $\mathrm{Hg}$ wet deposition to RGM dry deposition for eight sites located in the eastern United States and Puerto Rico were calculated from data in Engle et al. (2010). Engle et al. (2010) determine RGM dry deposition using continuous RGM concentration measurements and a numerical 
resistance-based deposition model. Miller et al. (2005) estimate higher annual fluxes of RGM dry deposition than $\mathrm{Hg}$ wet deposition for New Hampshire. In comparison the TF ratio for 2007 is within the range of values from Engle et al. (2010) for rural and coastal sites and the TF ratio for 2008 is slightly greater (excluding Puerto Rico). In contrast to the findings of Miller et al. (2005), results from our study, as well as those of Engle et al. (2010), demonstrate that annual $\mathrm{Hg}$ wet deposition fluxes are typically greater than RGM dry deposition fluxes. The observations hold across many different sites despite differences in geographic location and sampling years. The exception to this generalization is one urban site studied in Engle et al. (2010) in East St. Louis, IL, which likely stands out because of its large population ( 2.8 million) as well as the impact of several local anthropogenic sources.

\section{Summary and conclusions}

Total aqueous $\mathrm{Hg}$ in precipitation samples collected at $\mathrm{TF}$ in Durham, NH from July 2006 to September 2009 demonstrate seasonal $\mathrm{Hg}$ wet deposition and VWM concentration patterns consistent with previous observations for the northeastern United States with elevated values during the summer and spring seasons. Wet deposition samples from regional MDN sites collected during the same sampling interval exhibit similar seasonal patterns. Comparisons of the relative $\mathrm{Hg}$ precipitation concentrations and wet deposition fluxes between the TF and MDN sites suggest that the proximity to anthropogenic Hg sources may partially explain observed differences.

The quantity of precipitation also contributes to the seasonal and annual variations in $\mathrm{Hg}$ wet deposition. As observed at TF, the winter 2007-2008 and summer 2008 had above normal precipitation amounts and high $\mathrm{Hg}$ wet deposition fluxes. This relationship is also exhibited on an annual basis with the anomalously high amount of precipitation that fell during 2008 contributing to the very high annual $\mathrm{Hg}$ wet deposition flux for the year. While this observation may seem rudimentary (i.e. more precipitation equates to more wet deposition), it warrants noting as observed and predicted increases in precipitation amount and intensity in the midlatitudes due to climate change (Easterling et al., 2000) imply $\mathrm{Hg}$ wet deposition fluxes will also increase.

Our multi-year dataset and event-based sampling of $\mathrm{Hg}$ wet deposition and RGM measurements allows for seasonal comparisons. The inefficient scavenging of RGM by snowfall is evidenced by the less frequent depletion of RGM below the LOD during winter months. Although the winter wet deposition values are low, the RGM dry deposition estimates at TF indicate enhanced dry deposition in the winter. These seasonal changes in $\mathrm{Hg}$ deposition pathways are reflected in the seasonal ratios of $\mathrm{Hg}$ wet deposition to RGM dry deposition. These ratios differ greatly by season and range from a summer value of 79.6 to a winter value of 1.60. In general, the winter and spring ratios are lowest while the summer ratios are greatest. The elevated amounts of precipitation during 2008 likely influence our ratios of $\mathrm{Hg}$ wet to RGM dry deposition. The seasonality in the atmospheric Hg depositional mechanisms (wet vs. dry) may subsequently affect the fate and transport of $\mathrm{Hg}$ in aquatic and terrestrial ecosystems. Improved quantification of $\mathrm{Hg}$ wet and dry deposition, via long term simultaneous measurements and advances in measurement technology, will lead to a better understanding of the biogeochemical cycle of $\mathrm{Hg}$.

Acknowledgements. This work was made possible by NSF fellowships to MASL (from DGE-0338277 and GEO-0631377) and from ATM-0837833 to HM, RT, and JGB. Support was also provided by the Office of Oceanic and Atmospheric Research of the National Oceanic and Atmospheric Administration under AIRMAP grant \#NA06OAR4600189 to UNH.

Sampling and sample preparation assistance from Jennie Garcia, Sara Keach, Laura Nichols, Laura Preston, and Rosie Simpson, with field assistance from Kevan Carpenter and Cheryl Parker is gratefully acknowledged.

Edited by: J. B. Burkholder

\section{References}

Ariya, P. A., Dastoor, A. P., Amyot, M., Schroeder, W. H., Barrie, L., Anlauf, K., Raofie, F., Ryzhkov, A., Davignon, D., Lalonde, J., and Stefen, A.: The artic: a sink for mercury, Tellus, 56B, 397-403, 2004.

Bushey, J. T., Nallana, A. G., Montesdeoca, M. R., and Driscoll, C. T.: Mercury dynamics of a northern hardwood canopy, Atmos. Environ., 42, 6905-6914, 2008.

Chen, C. Y., Stemberger, R. S., Kamman, N. C., Mayes, B. M., and Folt, C. L.: Patterns of $\mathrm{Hg}$ bioaccumulation and transfer in aquatic food webs across multi-lake studies in the Northeast US, Ecotoxicology, 14, 135-147, 2005.

Chen, M., Talbot, R., Mao, H., Sive, B., Chen, J., and Griffin, R. J.: Air mass classification in coastal New England and its relationship to meteorological conditions, J. Geophys. Res., 112, D10S05, doi:10.1029/2006JD007687, 2007.

Choi, H. D., Sharac, T. J., and Holsen, T. M.: Mercury deposition in the Adirondacks: A comparison between precipitation and throughfall, Atmos. Eviron., 42, 1818-1827, 2008.

Darby, L. S., McKeen, S. A., Senff, C. J., White, A. B., Banta, R., Post, M. J., Brewer, W. A., Marchbanks, R., Alvarez II, R. J., Peckham, S. E., Mao, H., and Talbot, R.: Ozone differences between near-coastal and offshore sites in New England: Role of meteorology, J. Geophys. Res., 112, D16S91, doi:10.1029/2007JD008446, 2007.

Downs, S. G., MacLeod, C. L., and Lester, J. N.: Mercury in Precipitation and its relation to bioaccumulation in fish: a literature review, Water, Air and Soil Pollution, 108, 149-187, 2007.

Easterling, D. R., Meehl, G. A., Parmesan, C., Changnon, S. A., Karl, T. R., and Mearns, L. O.: Climate Extremes: Observations, Modeling, and Impacts, Science, 289, 2068-2074, 2000.

Engle, M. A., Tate, M. T., Krabbenhoft, D. P., Schauer, J. J., Kolker, A., Shanley, J. B., and Bothner, M. H.: Comparison 
of atmospheric mercury speciation and deposition at nine sites across central and eastern North America, J. Geophys. Res., 115, D18306, doi:10.1029/2010JD014064, 2010.

Evers, D. C., Han, Y. J., Driscoll, C. T., Kamman, N. C., Goodale, M. W., Lambert, K. F., Holsen, T. M., Chen, C. Y., Clair, T. A., and Butler, T.: Biological mercury hotspots in the northeastern United States and southeastern Canada, Bioscience, 5, 29-43, 2007.

Guentzel, J. L., Landing, W. M., Gill, G. A., and Pollman, C. D.: Processes influencing rainfall deposition of mercury in Florida, Environ. Sci. Tech., 35, 863-873, 2001.

Hall, B. D., Manolopoulos, H., Hurley, J. P., Schauer, J. J., St. Louis, V. L., Kenski, D., Graydon, J., Babiarz, C. L., Cleckner, L. B., and Keeler, G. J.: Methyl and total mercury in precipitation in the Great Lakes region, Atmos. Environ., 39, 7557-7569, 2005.

Han, Y., Holsen, T. M., Evers, D. C., and Driscoll, C. T.: Reduced mercury deposition in New Hampshire from 1996 to 2002 due to changes in local sources, Environmental Pollution, 156, 13481356, doi:10.1016/j.envpol.2008.02.021, 2008.

Holmes, C. D., Jacob, D. J., Mason, R. P., and Jaffe, D. A.: Sources and deposition of reactive gaseous mercury in the marine atmosphere, Atmos. Environ., 43, 2278-2285, doi:10.1016/j.atmosenv.2009.01.051, 2009.

Keeler, G. J., Gratz, L. E., and Al-Wali, K.: Long-term Atmospheric Mercury Wet Deposition at Underhill, Vermont, Ecotoxicology, 14, 71-83, 2005.

Kieber, R. J., Parler, N. E., Skrabal, S. A., and Willey, J. D.: Speciation and photochemistry of mercury in rainwater, J. Atmos. Chem., 60, 153-168, doi:10.1007/s10874-008-9114-1, 2008.

Landis, M. S. and Keeler, G. J.: Atmospheric mercury deposition to Lake Michigan during the Lake Michigan mass balance study, Environ. Sci. Technol., 36, 4518-4524, 2002.

Laurier, F. and Mason, R.: Mercury concentration and speciation in the coastal and open ocean boundary layer, J. Geophys. Res., 112, D06302, doi:10.1029/2006JD007320, 2007.

Lin, C. J. and Pehkonen, S. O.: The chemistry of atmospheric mercury: a review, Atmos. Enviro., 33, 2067-2079, 1999.

Lindberg, S. E. and Stratton, W. J.: Atmospheric mercury speciation: concentrations and behavior of reactive gaseous mercury in ambient air, Environ. Sci. Technol., 32, 49-57, 1998.

Lindberg, S., Bullock, R., Ebinghaus, R., Engstrom, D., Feng, X., Fitzgerald, W., Pirrone, N., Prestbo, E., and Seigneur, C.: A synthesis of progress and uncertainties in attributing the source of mercury in deposition, Ambio, 36, 19-32, 2007.

Mao, H. and Talbot, R.: $\mathrm{O}_{3}$ and $\mathrm{CO}$ in New England: Temporal variations and relationships, J. Geophys. Res., 109, D21304, doi:10.1029/2004JD004913, 2004.

Mao, H. and Talbot, R.: Speciated mercury at a marine, coastal, and inland sites in New England: Part 1. Temporal variabilities, Atmos. Chem. Phys. Discuss., in preparation, 2011.

Mao, H., Talbot, R. W., Sigler, J. M., Sive, B. C., and Hegarty, J. D.: Seasonal and diurnal variations of $\mathrm{Hg}^{\circ}$ over New England, Atmos. Chem. Phys., 8, 1403-1421, doi:10.5194/acp-8-1403-2008, 2008.

Mason, R. P. and Sheu, G. R.: Role of the ocean in the global mercury cycle, Global Biogeochem. Cycles, 16, 1093, doi:10.1029/2001GB001440, 2002.

Mason, R. P., Lawson, N. M., and Sheu, G. R.: Annual and seasonal trends in mercury deposition in Maryland, Atmos. Environ., 34,
1691-1701, 2000.

Miller, E. K., Vanarsdale, A., Keeler, G. J., Chalmers, A., Poissant, L., Kamman, N. C., and Brulotte, R.: Estimation and mapping of wet and dry mercury deposition across northeastern North America, Ecotoxicology, 14, 53-70, 2005.

NADP/MDN: National Atmospheric Deposition Program (NRSP3)/Mercury Deposition Network (2001), NADP Program Office, Illinois State Water Survey, 2204 Griffith Drive, Champaign, IL 61820, 2001-2009.

Nelson, S. J., Johnson, K. B., Weathers, K. C., Loftin, C. S., Fernandez, I. J., Kahl, J. S., Krabbenhoft, D. P.: A comparison of winter mercury accumulation at forested and no-canopy sites measured with different snow sampling techniques, Appl. Geochemistry, 23, 384-398, doi:10.1016/j.apgeochem.2007.12.009, 2008.

NHDES (New Hampshire Department of Environmental Services): Air Pollution Transport and How it Affects New Hampshire. NHDES, Concord, New Hampshire, 2004.

Prestbo, E. M. and Gay, D. A.: Wet deposition of mercury in the U.S. and Canada, 1996-2005: Results and analysis of the NADP mercury deposition network (MDN), Atmos. Environ., 25, 42234233, 2009.

Rea, A. W., Lindberg, S. E., Scherbatskoy, T., and Keeler, G. J.: Mercury accumulation in foliage over time in two northern mixed hardwood forests, Water, Air, Soil Pollut., 133, 49-67, 2002.

Russo, R. S., Zhou, Y., Haase, K. B., Wingenter, O. W., Frinak, E. K., Mao, H., Talbot, R. W., and Sive, B. C.: Temporal variability, sources, and sinks of $\mathrm{C}_{1}-\mathrm{C}_{5}$ alkyl nitrates in coastal New England, Atmos. Chem. Phys., 10, 1865-1883, doi:10.5194/acp10-1865-2010, 2010.

Sakata, M. and Asakura, K.: Estimating contribution of precipitation scavenging of atmospheric particulate mercury to mercury wet deposition in Japan, Atmos. Environ., 41, 1669-1680, doii:10.1016/j.atmosenv.2006.10.031, 2007.

Schroeder, W. H. and Munthe, J.: Atmospheric mercury- an overview, Atmos. Environ., 32(5), 809-822, 1998

Selin, N. E.: Global biogeochemical cycling of mercury: a review, Annu. Rev. Environ. Resourc., 34, 43-63, 2009.

Selin, N. E. and Jacob, D. J.: Seasonal and spatial patterns of mercury wet deposition in the United States: Constraints on the contribution from North American anthropogenic sources, Atmos. Environ., 42, 5193-5204, 2008.

Selvendiran, P., Driscoll, C. T., Montesdeoca, M. R., and Bushey, J. T.: Inputs, storage, and transport of total methyl mercury in two temperate forest wetlands, J. Geophys. Res., 113, G00C01, doi:10.1029/2008JG000739, 2008.

Sigler, J. M., Mao, H., Sive, B. C., and Talbot, R.: Oceanic influence on atmospheric mercury at coastal and inland sites: a springtime noreaster in New England, Atmos. Chem. Phys., 9, 4023-4030, doi:10.5194/acp-9-4023-2009, 2009a.

Sigler, J. M., Mao, H., and Talbot, R.: Gaseous elemental and reactive mercury in Southern New Hampshire, Atmos. Chem. Phys., 9, 1929-1942, doi:10.5194/acp-9-1929-2009, 2009b.

Sorensen, J. A., Glass, G. E., and Schmidt, K. W.: Regional patterns of wet mercury deposition, Environ. Sci. Tech., 28(12), 20252032, 1994.

Steding, D. J. and Flegal, A. R.: Mercury concentration in coastal California precipitation: Evidence of local and trans-Pacific fluxes of mercury to North America, J. Geophys. Res., 107(D24), 
4764, doi:10.1029/2002JD002081, 2002.

Talbot, R., Mao, H., and Sive, B.: Diurnal characteristic of surface level $\mathrm{O}_{3}$ and other important trace gases in New England, J. Geophys. Res., 110, D09307, doi:10.1029/2004JD005449, 2005.

VanArsdale, A., Weiss, J., Keeler, G., Miller, E., Boulet, G., Brulotte, R., and Poissant, L.: Patterns of mercury deposition and concentration in northeastern North America (1996-2002), Ecotoxicology, 14, 37-52, 2005.
Yatavelli, R. L. N., Fahrni, J. K., Kim, M., Crist, K. C., Vickers, C. D., Winter, S. E., and Connell, D. P.: Mercury, $\mathrm{PM}_{2.5}$ and gaseous co-pollutants in the Ohio River Valley region: Preliminary results from the Athens supersite, Atmos. Environ., 40, 6650-6665, 2006.

Zhang, L., Wright, L. R., and Blanchard, P.: A review of current knowledge concerning dry deposition of atmospheric mercury, Atmos. Environ., 43, 5853-5864, 2009. 